\title{
Imagining France as an Islamic State: Identity Construction in Michel Houellebecq's Soumission
}

\author{
Andi Mustofa \\ Universitas Negeri Yogyakarta, Indonesia \\ Email: andimustofa@uny.ac.id
}

\begin{abstract}
The regime change in France, which puts the Islamic group in a dominant position, has changed the structure of the French Republic. The dynamics of social relation transformation cause shifts in the status of social groups such as Islam, Atheists, Jews, and Catholics in social relation patterns. This descriptive qualitative research aims at revealing the form of exclusivity, resistance, and negotiation in the construction of identity performed by the characters in Soumission. The analysis is based on the concept of identity. The results of this research are the exclusive identities of Islamic group are portrayed through the education and political system and the position of women in social relation; the forms of resistance as a strategy in the construction of identity are made through demonstration, mobilization, exploitation of the body, and rejection of the use of religious symbols; the forms of negotiation are done by accepting and rejecting Islamic laws applied by the Islamic group.
\end{abstract}

Keywords: France, identity, Islam, negotiation, resistance.

\section{INTRODUCTION}

In January 2015, Michel Houellebecq published his novel Soumission which becomes a debate because of the sensitivity of the theme: France becomes an Islamic State. Soumission tells the dominance of the Islamic group in France, which changes the social group position in French society. These changes include the Islamisation of the universities in France, the obligation for teachers to be Muslim to be able to teach, the legalization of polygamy, the obligation to cover hair for women by using burqa and the prohibition of working for women.

Although the story in Soumission is the result of the author's imagination, Michel Houellebecq uses real French politicians as the characters such as French president François Hollande, French prime minister Manuel Valls, leader of the Front National Marine Le Pen, politician François Bayrou and Jean-François Copé. The use of French characters in the novel indirectly gives the effect that the story in Soumission is true. The similarity of the situation and condition of France in real fact with the case in the novel is one of the factors of this novel's success. The deep-rooted fear of Islam in France brought a loud reception, not only to this novel but also to the government. The government continues to be forced to blockade immigrants who are still entering France. The response of Soumission was worsened by the condition of the French state, which was in a precarious situation. The issue of immigrants, racism, political warfare between parties is widely discussed and blamed as a trigger for the crisis in France.

France recognizes the principle of laïité which has become part of the tradition and identity of the French Republic, which is based on freedom, equality of men and women, equality of opportunity, rights, and obligations, and a sense of brotherhood between citizens regardless of the background of each individual (Bruley, 2005). Soumission's story is focused on the domination of the Islamic identity group in France and the abolition of laïcité, which is replaced with Islamic laws. Although Soumission is considered as a fiction, Houellebecq used real data as a source of stories, such as the enhancing of Islam in France which is a social fact, even though its reinforcement has not been able to rule all of France as told in the novel. Houellebecq has tried to make a narrative about the Islamic group, which controls the French Republic identity. The Islamic group becomes the dominant group, while the non-Islamics groups such as Catholic, atheist, and Jews become the groups which are dominated.

Identity is the result of the individual interaction with other individuals or other groups and also the mixing and cultures movement (Hermans, 2001). Marc (2005) explains that identity is self-perception, but the discourse of the other continually mediates this perception. Identity is a process that never stops or established. The 
identity will always be constructed, reconstructed and also negotiated by individuals during the process of interaction in the context of forming their identity.

In his book Social Identity, Jenkins (2008) states that identity is related to a meaning which is socially constructed because identity is a part of social life. Social interaction is a process that must be passed in the formation of identity. Identity construction will always take place from two directions that are formed through relationships with others. During the process, individuals will find an impression on themselves and also on other individuals. In other words, individuals will discover similarities and differences between themselves and other individuals in social relation.

Castells (2004) argues that the general principle of society is that when there is domination, there will be resistance (rejection) to power. Conflict will arise as a result of domination if it is done on a large scale. Furthermore, Woodward (2002) explains that the oppressed groups do not merely accept a forced identity but negotiate by rejecting or accepting that identity. This negotiation is defined as a "transactional interaction process whereby individuals in an intercultural situation attempt to assert, define, modify, challenge, and/or support their own and others' desired self-images" (Ting-Toomey, 1999). In other words, negotiation and resistance are a form of acceptance as well as rejection and legitimacy of the existence of others in the process of interaction between individuals.

Soumission emerged as a tool to convey discourse about Islam that is increasingly spreading France. Michel Houellebecq gives rise to Islam as an exclusive group that occupies a high social class, respected, and has political, economic, and social power in France. The dominant Islamic group that changes all state rules based on Islamic law influences the position of non-Islamic groups in France. The strength of the ruling regime requires that non-Islamic groups obey the rules that have been constructed by their social environment. Even so, the dominated groups actively carry out resistance and negotiation to form an identity as a form of adaptation to the new social structure. The resistance may take the form of passive resistance or active resistance by reducing, eliminating, or challenging the institutional hierarchies that oppress (Martin, 2010). Thus, the research questions in this study are the exclusivity of Islamic groups positioned by the author and the form of resistance and negotiation as an identity construction process reflected in Soumission.

\section{METHODOLOGY}

This study is descriptive qualitative research. The analysis is based on the concept of identity. The data source of this research is Soumission a novel written by Michel Houellebecq and published in 2015 by Flammarion. The steps of analysis to answer question-related to exclusivity are as follows: 1) finding the action of exclusivity showed by an Islamic group in Soumission, 2) showing the particular practices which can distinguish the identity of one character with the other characters.

The subsequent analysis is to identify the contestation in the form of resistance and negotiation in the identity construction process. The analysis was conducted as follows: 1) exploring the possibility of the subject domination to the other subjects in their interaction process, 2) showing the resistance practices by the subjects which are dominated, 3) showing the forms of the subject negotiation as a result of the dominance practices.

\section{RESULTS AND DISCUSSION}

\section{Exclusive Identity of Islam in France}

The exclusivity of Islamic identity tends to negate the non-Islamic groups. The superiority of Islam is present in the form of privileges in public as well as the domestic domain. This superiority implies a desire to determine identity. The type of Islamic exclusivity is shown in the following passage.

"Vêtues pendant la journée d'impénétrables burqas noires, les riches Saoudiennes se transformaient le soir en oiseaux des paradis, se paraient de guêpieres, de soutiens-gorge ajourés, de strings ornés de dentelles multicolores et de pierreries ; exactement l'inverse des Occidentales, classe et sexy pendant la journée" (p. 91)

"Dressed during the day in impenetrable black burqas, the rich Saudi women transformed themselves in the evening into birds of paradise, adorn themselves with basques, openwork bras, thongs adorned with multicoloured lace and precious stones; just the opposite of Western women, classy and sexy during the day" (p. 91)

The word impénétrables (impenetrable) implies the confidentiality of the women identity by wearing a burqa. The nature of burqa, which is impénétrables from the outside but allows the wearer overseeing the others provides the exclusivity of a religious symbol. Women in burqa actively define others but at the same time, using the burqa as religious symbols prevents others from 
defining the individual inside burqa. The others can only define the individual inside burqa based on their religious symbol, not by their personal things in depth. That exclusivity is used to negate individuals outside the Islamic group. The exclusivity of women is shown by metaphor oiseaux des paradis (birds of paradise) to describe women in Islam. Women are portrayed as birds of paradise that show the high quality of women in Islam like God's heaven.

All exercise of power is a limitation of freedom (Popitz, 2017). In Soumission, under the regime of Islam, education has to be based on Koran, the source of Islamic laws. The form of exclusivity in Islamic identity is the obligation of the society to follow an Islamic education from the primary to university.

"Chaque enfant français doit avoir la posibilité de bénéficier, du début à la fin de sa scolarité, d'un enseignement islamique" (p. 82)

"Every French child should have the opportunity to benefit from the beginning to the end of his schooling, an Islamic education" (p. 82)

Islamic education is an attempt to perpetuate the Islamic ideology. Education-based on Islamic law is used as a hegemony tool to state the quality of education. The school that bases on other concepts are considered to have inadequate quality. The only knowledge that is deemed to be true is the one with Islam base.

"Aujourd'hui c'était l'Islam, religion [...], plus récente, plus simple et plus vrai" (p. 275)

"Today it was Islam, a newer, simpler and truer religion" (p. 275)

Education has never been free of political interests to perpetuate the existing socio-economic system and existing power. This view also assumes that education is always used to preserve or legitimize their dominance. In other words, education is a way to maintain power to stay in place. Therefore, the general nature of education for them is nothing more than a means to produce social systems and structures that are unjust, such as class relation, gender, racism, or other relation systems.

Education as a means of perpetuating the existing power structure is done through the forcible transfer of knowledge. Individuals are dictated to receive an Islamic education. The assumption that Islam, religion plus vrai (Islam, the most valid religion) confirms the position of Islam in social relation. Interreligious relation becomes misaligned, which results in an imbalance in religious, social relation.

In Soumission, teachers at every level of education are required to be Muslim. Islamic exclusivity in education is demonstrated by not accepting non-Muslim teachers. This exclusivity is a form of the legitimacy of the Islamic regime in education. The obligation of these Muslim teachers at the same time explains that the teaching of Islam is closed and can only be done by Muslims. Islamic teachers are considered as a group that symbolizes the progress of thought, modernity, and elite social class. Schools as educational institutions are not free from the ideology of the ruling regime.

In the context above, Muslim teachers become identity-forming tools and being a means of transferring knowledge. Islamic identity is gradually constructed through education from elementary to tertiary level. As an implementation, non-Muslim teachers do not get the opportunity to teach the class. To be able to join an educational institution, becoming a Muslim is a must.

The Islamic Republic of France is a country based on the principles of Islamic ideology. Therefore, the laws of daily life must obey the Koran.

"Les règles concernant l'alimentaire des cantines, le temps dévolu aux cinq prières quotidiennes devront être respectés. Le programme scolaire devra être adapté aux enseignements du Coran" (p. 82)

"The rules regarding food in the canteens, the time allocated to the five daily prayers must be respected. The curriculum will have to be adapted to the teachings of the Koran" (p. 82)

The exclusivity of Islam is shown by the rules related to the worship of God. The important thing in the Islamic regime is Islam and its followers who can do their obligation as a Muslim easily.

\section{Resistance and Negotiation in the Identity Con- struction Process}

The power of the ruling regime also influenced the formation of social identity in French society. In Soumission, the power of the Islamic group can dominate the minority group within the French community. Therefore, non-Islamic groups fight the dominant force in the form of resistance. This condition is under Gramsci's opinion that social conditions in conflict with the dominant group will lead to resistance (Fiske, 2007:245).

The resistance that emerges in Soumission is a form of resistance to power. The rise of the Islamic government in France are forms of majority domination, both subtle and extreme, over non-Islamic minority groups. The type of resistance that arises is a demonstration carried 
out by non-Islamic groups who oppose the Islamic group in France.

The laïcité is the principle of freedom and respect for differences (https://www.gouvernement.fr/qu-est-ce-que-la-laicite). This principle is applied in the public administration system in the French Republic (Moatti, 2004). In Soumission, the abolition of the laïcité system and its replacement with the Islamic regime as well as the violation of the ideas of liberté (freedom), égalité (equality) and fraternité (brotherhood) receive a strong rejection from people who have ideologies at odds with the ruling regime. The rejection of Islamic law in France is carried out through demonstrations as a form of resistance to the dominance of Islamic law applied in state life. Demonstrations of the French people are carried out to reject several things. The first refusal is that teachers are required to have Islamic status to be able to teach in educational institutions. The rule is considered to hamper non-Muslim to occupy educational posts. In social life, women are also required to wear a head covering as a form of compliance with Islamic regulations. The necessity to use the burqa is considered as an effort to limit women's movements.

When the ruler becomes very oppressive, resistance emerges in the form of a migration strategy. Displacement is an effort to distance from the space of domination. In this case, the French Islamic Republic. Individuals will look for areas that are free from domination which will not affect their identity. In Soumission, the return of several Jewish groups to Israel is a form of their resistance to the dominance of Islamic groups in France. Migration is carried out as an effort to maintain their exclusive identity as members of Jewish groups.

The resistance of non-Islamic groups is done by not obeying Islamic rules. The practice of prostitution and free sex continues to be carried out by the main character François to fulfil his sexual desires. The satisfaction of sexual desires is done by hiring sex workers, and even François chooses a Muslim sex worker.

"Je n'avais fait que très occasionnellement appel à des sites d'escorts, je l'avais fait le plus souvent pendant le mois d'été [...] ça m'excitait assez, compte tenu des circonstances politiques globales, de choisir une musulmane" (p. 185)

"I had only very occasionally used escort sites, I had done so most often during the summer month [...] it excited me enough, given the global political circumstances, to choose a Muslim" (p. 185)
As an activity that violates religious boundaries, prostitution is considered as an illegal practice because it has sexual relations without being based on a legal marriage agreement. Sexual behaviour carried out by François is a form of resistance to Islamic rules implemented by the ruling regime. The selection of Muslim partners in the practice of prostitution shows this form of refusal to comply with Islamic laws imposed on non-Islamic minority groups.

Although in Soumission, Islam is dominant, there will always be practices that deny their existence. The practices of violation of Islamic rules are a critique of Islam which is considered not open to non-Islamic cultures. The practice of alcohol consumption carried out by Islamic leaders in Soumission is a form of accepting and rejecting Islamic rules. They accept Islam as a new identity but reject laws that conflict with previous identities.

Swann and Bosson (2010) state that "identity negotiation processes define relationships and make them viable as a foundation for organized social activity". In the context of Soumission, women are required to use the burqa as a sign of their identity and a form of adherence to religion. Negotiations on these Islamic rules are carried out by wearing these clothes during the day and taking them off at night. The efforts to negotiate Islamic law are carried out concerning certain times which are considered safe such as night time.

The negotiation in marriage is carried out by the ruling regime group. The French state recognizes three forms of marriage, namely le mariage, le PACS, and le concubinage (Rault, 2007). These three forms allow both different or samesex couples to live together. The difference in these three forms is the formality before marriage and the various rights and obligations that bind it. This marriage form that is unknown in Islam is maintained under the French Islamic regime. This negotiation is an integrated strategy with French society.

\section{CONCLUSION}

The dominant position of the Islamic group in France has changed the social structure in French society. In Soumission, the exclusivity of Muslim women is portrayed in social relations with other individuals or groups in the form of a burqa. Islamic education is an attempt to perpetuate the Islamic ideology. Therefore, education must be based on the teaching system based on the Koran. The exclusivity of the Islamic group 
can also be seen from the recruitment of teaching staff who have to be Islam. The exclusivity of Islam in politics is the implementation of the policies which are more aligned to the Islamic group.

In Soumission, the non-Islamic groups are dominated by an Islamic group in France that cause resistance and negotiation as a strategy in the identity construction. The resistance forms that emerge are the demonstration by the non-Islamic groups which refuse the domination of the Islamic group. When the authority becomes very aggressive, a mobilization becomes the resistance strategy. Another strategy used by social actors is the exploitation of the body through prostitution. The rejection of religious attributes is a form of individual strategy to reject the Islamic rules applied in France. The interaction process will encourage the negotiation as a strategy of conflict prevention caused by the distinctive identity. The negotiation is done through the use of burqa during the day and not using it at night. The negotiation is also done by the dominant group to accommodate the principles of non-Islamic practices such as marriage.

Michel Houellebecq describes the Islamic group as an exclusive group that cannot be penetrated by the other groups. There is a fear of the author when Islam comes to power. This fear is based on the dominance of Islamic groups that are considered to have damaged relation between social groups that were previously formed. However, the author tries to unify the concepts of Islam and France through social practices legitimized by the Islamic group as the ruling group. The unification of the two concepts in Islam and France is an attempt to eliminate the dichotomy of we and they, in groups and out groups that separate one from the other.

\section{REFERENCES}

Bianco, J-L. Qu'est-ce que la laïcité? https://www.gouvernement.fr/qu-est-ce-que-la-laicite

Bruley, Y. (2005). l'Histoire de la Laïcité en France. Paris: Académie des Sciences Morales et Politiques.

Castells, M. (2004). The Power of Identity: The Information Age: Economy, Society, and Culture. Malden: Blackwell Publishing.

Fiske, J. (2007). Cultural and Communication Studies: Sebuah pengantar paling komprehensif. Yogyakarta: Jalasutra.

Hermans, H. J. M. (2001). The dialogical self: Toward a theory of personal and cultural positioning, Culture and Psychology, 7, p. 243-281.

Houellebecq, M. (2015). Soumission. Paris: Flammarion.

Jenkins, R. (2008). Social Identity (3rd ed.). London and New York: Routledge

Marc, E. (2005). Psychologie de l'identité: soi et le groupe, Paris: Dunod.

Martin, J.N., \& Nakayama, T. (2010). Intercultural Communication in Context. New York: McGraw-Hill.

Moatti, D. (2004) La laïcité ou l'histoire mouvementée d'un concept français, Pyramides, 8, 83-98.

Popitz, H. (2017). Phenomena of Power: Authority, Domination, and Violence translated by Gianfranco Poggi. New York: Columbia University Press.

Rault, W. (2007). Entre droit et symbole. Les usages sociaux du pacte civil de solidarité, Revue française de sociologie, 48(3), 555-586.

Swann, W. B., Jr., \& Bosson, J. K. (2010). Self and identity. In Handbook of social Psychology. New York: McGraw-Hill.

Ting-Toomey, S. (1999). Communicating Across Cultures. New York: The Guilford Press.

Woodward, K. (2002). Understanding Identity. London: Arnold Publication. 